\title{
PECKING ORDER VERSUS TRADE-OFF: AN EMPIRICAL APPROACH TO THE SMALL AND MEDIUM ENTERPRISE CAPITAL STRUCTURE*
}

\section{Francisco Sogorb-Mira y José López-Gracia**}

WP-EC 2003-09

Correspondence to: Francisco Sogorb, Departamento de Economía y Empresa (Universidad Cardenal Herrera-CEU), Elche (Alicante), Spain, fsogorb@uch.ceu.es.

Editor: Instituto Valenciano de Investigaciones Económicas, S.A.

Primera Edición Junio 2003

Depósito Legal: V-2871-2003

IVIE working papers offer in advance the results of economic research under way in order to encourage a discussion process before sending them to scientific journals for their final publication.

* This paper is based on Chapter IV of the doctoral dissertation "The determinants of SMEs capital structure: an empirical approach to the Spanish case" by Francisco Sogorb-Mira, supervised by José López-Gracia, at Alicante University. The authors would like to thank the evaluation committee members Juan Carlos Gómez Sala, Julio Pindado García, Clara Cardone Riportella, Pedro Martínez Solano and Mariano González Sánchez for their valuable comments and suggestions. This paper has also benefited from research assistance received from Cristina Aybar Arias and Alejandro Casino Martínez, in addition to the helpful comments from an Ivie reviewer.

** F. Sogorb-Mira: Universidad Cardenal Herrera-CEU (Elche); J. López-Gracia: Universitat de València. 


\title{
PECKING ORDER VERSUS TRADE-OFF: AN EMPIRICAL APPROACH TO THE SMALL AND MEDIUM ENTERPRISE CAPITAL STRUCTURE
}

\author{
Francisco Sogorb-Mira and José López-Gracia
}

\begin{abstract}
In this paper, we explore two of the most relevant theories that explain financial policy in small and medium enterprises (SMEs): pecking order theory and trade-off theory. Panel data methodology is used to test the empirical hypotheses over a sample of 6482 Spanish SMEs during the five-year period 1994-1998. The results suggest that both theoretical approaches contribute to explain capital structure in SMEs. However, while we find evidence that SMEs attempt to achieve a target or optimum leverage (trade-off model), there is less support for the view that SMEs adjust their leverage level to their financing requirements (pecking order model).
\end{abstract}

Keywords: Pecking Order, Trade-off, Capital Structure, Small and Medium Enterprises, Panel Data.

JEL: C34, G32, G33.

\section{RESUMEN}

En este trabajo, exploramos dos de las teorías más relevantes que explican la política de financiación de la pequeña y mediana empresa: la selección jerárquica y el equilibrio estático. El contraste de hipótesis se lleva a cabo con metodología de datos de panel, a partir de una muestra de 6482 pymes españolas, que presentan información financiera a lo largo del periodo 1994-1998. Los resultados indican que ambos enfoques contribuyen a explicar la estructura de capital de las pymes, si bien mientras que se confirma la existencia de un endeudamiento objetivo u óptimo que estas empresas tratan de alcanzar (modelo de equilibrio estático), no parece quedar claro que ajusten su nivel de deuda a sus necesidades de financiación (modelo de selección jerárquica).

Palabras clave: selección jerárquica, equilibrio estático, estructura de capital, pymes, datos de panel. 


\section{Introduction}

The vast majority of empirical studies that analyse the determinants of firm financing usually examine large publicly listed companies with a widely spread ownership. These companies often raise finance by issuing corporate debt on the capital markets (Zingales, 2000, p. 1629). In this paper, we examine the financing of small and medium sized companies (SMEs) and explore whether the main theories of firm financing can explain the capital structure of these firms.

SMEs often suffer the problems associated with asymmetric information, such as adverse selection and moral hazard. In this way, they are affected by the typical problems studied in the theory of pecking order. Nevertheless, these firms could also set their financial policy by following a target indebtedness ratio, as maintained by tradeoff theory. As both theories, pecking order and trade-off, enable us to describe the financial behaviour of SMEs with some accuracy, we develop the behavioural models necessary to analyse which of the two theories best fits the characteristics of these companies and explains their actions.

Our starting point is that established by Shyam-Sunder and Myers (1999), when developing the analysis of SME financing. This point has been adapted to our specific context, and following the lines suggested by Chirinko and Singha (2000), we propose alternative verification methods in order to give our results greater robustness.

A revision of the empirical literature leads us to conclude that there is insufficient clarity in the degree of applicability of the various theories of firm leverage. Rajan and Zingales (1995) clearly arrive at the same conclusion, while Graham (1996) asks why we cannot better empirically explain firm leverage - given the wide number of available theories. Shyam-Sunder and Myers (1999) argue that a possible solution to this question may arise from a meticulous study of the predictions associated with each theory, rather than an attempt to simultaneously collect together all the theories. This provides the motivation for our proposal to centre an empirical analysis on a model representing trade-off, and another representing pecking order.

Our research exploits the characteristics of data panel and incorporates dynamic effects, while controlling temporary, as well as specific unobservable company effects. 
As a result, we obtain a base that is more appropriate for analysing the financial decisions taken by SMEs.

The rest of the paper has been organised as follows. Sections 2 and 3 tackle the theoretical foundations of pecking order and trade-off. The available literature and hypotheses to be verified are also discussed. In Section 4, the process of sample selection is explained and the data is also described. Section 5 covers the methodology used and discusses the principal problems of estimating with panel data models. Section 6 presents the results obtained and verifies the defined hypotheses. Lastly, section 7 sums up the main conclusions of the research.

\section{Trade-off model}

\section{A. Background and theoretical foundation}

In this theoretical framework, companies identify their optimal capital structure and weigh up the advantages and disadvantages of an additional monetary unit of debt. Among the advantages, we can include costs that are 'fiscally deductible' from company tax as a result of paying interests (Modigliani and Miller, 1963; DeAngelo and Masulis, 1980); and a lessening of the free cash flow problem (Jensen, 1986; Stulz, 1990). The disadvantages of debt include the potential costs resulting from financial distress (Kraus and Litzenberger, 1973; Kim, 1978), and the agency costs arising between owners and financial creditors (Jensen and Meckling, 1976; Myers, 1977). At the optimal point for the company capital structure, the benefits and shortcomings of debt are balanced - so achieving equilibrium. Myers (1984) showed that the trade-off approach implied that the rate of real company indebtedness reverts to a target, or optimal level.

Following this line of reasoning, we propose verifying the prediction of the trade-off theory with respect to the reversion of leverage towards an objective, or optimal point; and estimate the speed with which this adjustment is made. As Fama and French (2002) show, empirical studies made within the framework of trade-off theory and aimed at identifying the determinants of company indebtedness normally estimate a simple cross-section regression - estimating the relation existing between the ratios of observed debt and a set of explanatory variables using non-dynamic models (vid, for example, Bradley et al., 1984, Titman and Wessels, 1988, and Rajan and Zingales, 
1995). This type of approach suffers two limitations: (i) observed debt does not necessarily have to be identified with optimal debt, as this implies ignoring the difficulties companies suffer when adjusting their capital structure (Myers, 1977); and (ii) static empirical analysis is unable to explain the dynamic nature of company capital, that is to say, it does not really examine whether company debt shows a reversion to a given objective optimal level, and how quickly this reversion occurs. In fact, there are relatively few papers that analyse the dynamic aspect of capital structure and among them we can highlight: Lev and Pekelman (1975), Ang (1976), Taggart (1977), Marsh (1982), Jalilvand and Harris (1984), Auerbach (1985), Opler and Titman (1993) and Allen and Clissold (1998), although with fairly small sample. More recently we can point to: Shyam-Sunder and Myers (1999), Banerjee et al. (2000), Ozkan (2000), Hovakimian et al. (2001), Miguel and Pindado (2001), Nuri and Archer (2001), Omet (2001), Ozkan (2001), Antoniou et al. (2002) and Fama and French (2002).

In a perfect world, without transaction and adjustment costs, companies would automatically respond to any variation of their debt objective by increasing or decreasing the capital. So, in a given moment of time $t$, the observed debt of a given company, $\left(D_{i t}\right)$, should not differ from its debt target $\left(D^{*}{ }_{i t}\right)$, that is, $D_{i t}=D^{*}$ it. Nevertheless, in reality there are considerable transaction costs that impede companies from completely reaching $\mathrm{D}^{*}$ it, so the adjustment is, in this case, partial. We can represent this process using the following partial adjustment model:

$$
D_{i t}-D_{i t-1}=\lambda_{i t} \cdot\left(D_{i t}^{*}-D_{i t-1}\right)
$$

$\mathrm{D}_{\text {it }}$ being the ratio of total observed leverage, $\mathrm{D}^{*}$ it the ratio of target debt, and $\lambda_{\text {it }}$ its speed of adjustment. The equation [1] establishes up to which point the desired adjustment (from the debt ratio in $\mathrm{t}-1$ to the target ratio in $\mathrm{t}$ ) depends on its adjustment parameter $\lambda_{\text {it. }}$ According to the trade-off theory, this adjustment coefficient should have an appreciably positive value - near to 1 . If $\lambda_{\text {it }}=1$, this implies that the real debt coincides with the debt objective, that is, the capital structure of the company instantly and continuously adjusts to its objective value. As $\lambda_{\text {it }}$ can vary in companies, and over time for the same company, only if $\lambda_{\text {it }}=1$ for all $\mathrm{t}$ can we safely state that company $\mathrm{I}$ is consistently reaching its debt objective (complete adjustment). If $\lambda_{\text {it }}<1$, the adjustment from the period t-1 to t, has only partially achieved its debt objective; on the other hand, if $\lambda_{\text {it }}>1$, then an over-adjustment has occurred and the company has not achieved its capital structure objective. It should be noted that as $\lambda_{\text {it }}$ represents the degree of 
adjustment for the period, it can also be seen as the adjustment speed, and in this way a high value for $\lambda_{\text {it }}$ indicates quicker adjustment.

The estimation of the previous model can be undertaken with a two-stage regression analysis. As the debt objective is not directly observable, a proxy is used. The first stage consists of a regression analysis that incorporates those explanatory variables that correspond to those determinants of firm debt that are usually mentioned in the literature. In this way, a value that can serve as an estimation of the objective is obtained. For company i, in moment $t$, we will have the following equation:

$$
\mathrm{D}_{\mathrm{it}}^{*}=\mathrm{a}+\sum_{\mathrm{k}} \mathrm{b}_{\mathrm{k}} \cdot \mathrm{V}_{\mathrm{k}_{\mathrm{it}}}+\mathrm{c}_{\mathrm{i}}+\mathrm{c}_{\mathrm{t}}+\mathrm{e}_{\mathrm{it}}
$$

where the companies are represented by the sub-index $i=1, \ldots, n$, and time is shown as $t$ $=1, \ldots, \mathrm{T} . \mathrm{V}_{\mathrm{k}}$ is the vector that takes in the $\mathrm{k}$ explanatory variables that correspond to the specific company characteristics. The terms $b_{k}$ represent the unknown parameters associated with earlier variables. $c_{i}$ are the specific unobservable individual effects for each company from the panel, and which do not vary over time, and are identically and independently distributed (iid) with a variance $\sigma_{c}^{2}$. Examples of these effects include aspects of managerial behaviour such as motivation, skill and performance in the development of their functions, or attitudes towards risk. In addition, $c_{i}$ may include the specific effects of the economic sector where the firm operates, which is supposed to be constant over time, like entry barriers, conditions of the input market and the economic risk of the industry. The variable $c_{t}$ captures any specific temporal effect. These temporal effects include macroeconomic factors such as inflation, interest rates and demand shocks. Finally, $e_{i t}$ is an error term, which captures possible measurement errors in the independent variables, and any other explanatory variables which have been omitted. It is assumed that these errors are identical and independently distributed (iid), according to a Normal distribution with zero mean and a constant variance $\left(\mathrm{e}_{\mathrm{it}} \approx \mathrm{iid} \mathrm{N}\left(0, \sigma_{\mathrm{e}}^{2}\right)\right)$. In addition, it is assumed that errors do not present serial correlation.

Later, in the second stage, the adjusted values in the regression equation [2] are taken as a proxy of the target debt ratio in the estimation of the equation [1].

The verification of the static equilibrium theory can also be made in a single step, if we had previously and adequately combined equations [1] and [2]. In this way, substituting [2] in [1] and reorganising the terms of the resulting equation: 


$$
D_{i t}=\lambda_{i t} \cdot a+\left(1-\lambda_{i t}\right) \cdot D_{i t-1}+\lambda_{i t} \cdot \sum_{k} b_{k} \cdot V_{k_{i t}}+\lambda_{i t} \cdot c_{i}+\lambda_{i t} \cdot c_{t}+\lambda_{i t} \cdot e_{i t}
$$

By simplifying the above equation we arrive at:

$$
\mathrm{D}_{\mathrm{it}}=\delta+\alpha \cdot \mathrm{D}_{\mathrm{it}-1}+\sum_{\mathrm{k}} \beta_{\mathrm{k}} \cdot \mathrm{V}_{\mathrm{k}_{\mathrm{it}}}+\eta_{\mathrm{i}}+\eta_{\mathrm{t}}+\varepsilon_{\mathrm{it}}
$$

where $\delta=\lambda_{\text {it }} \cdot \mathrm{a}, \alpha=\left(1-\lambda_{\mathrm{it}}\right), \beta_{\mathrm{k}}=\lambda_{\mathrm{it}} \cdot \mathrm{b}_{\mathrm{k}}, \eta_{\mathrm{i}}=\lambda_{\mathrm{it}} \cdot \mathrm{c}_{\mathrm{i}}, \eta_{\mathrm{t}}=\lambda_{\mathrm{it}} \cdot \mathrm{c}_{\mathrm{t}}$ and $\varepsilon_{\mathrm{it}}=\lambda_{\mathrm{it}} \cdot \mathrm{e}_{\mathrm{it}}$ ( $\varepsilon_{i t}$ has the same properties as $e_{i t}$ ). Note that the parameter of the variable corresponding to the debt ratio delayed by one period is 1 minus the adjustment coefficient, meaning the transaction costs.

\section{B. Hypotheses and variables}

The general hypotheses that we intend verifying with this model, as implied in equation [3], have been taken from the empirical literature and are as follows:

"Companies follow a process of capital structure adjustment that leads to an optimal leverage level over the long-term" (Lev and Pekelman, 1975, Ang, 1976, Taggart, 1977, and Jalilvand and Harris, 1984).

The verification of this hypothesis is undertaken with an analysis of the estimated $\alpha$ parameter.

(2) "The effective tax rate should be positively related to the debt level" (Haugen and Senbet, 1986, Scott, 1976, and DeAngelo and Masulis, 1980).

The verification of this hypothesis is made using the effective tax rate (ETR) variable, which is defined as the ratio between tax paid and earnings after interest and before tax (EAIBT).

(3) "Non-debt tax shields should be negatively related to firm debt" (DeAngelo and Masulis, 1980).

This hypothesis can be verified using the non-debt tax shields (NDTS) variable, measured using the ratio between depreciation and assets.

(4) "Default risk should be negatively related to firm's debt ratio" (Bradley et al., 1984, and Mackie-Mason, 1990). 
The variable default risk (DR) is obtained using the ratio between interest expenses and earnings before interest and tax (EBIT).

(5) "Companies with greater growth opportunities will have a greater potential problem of under investment associated with debt financing, and therefore, a smaller target debt ratio" (Jensen and Meckling, 1976, Myers, 1977, and Stulz, 1990).

This hypothesis is verified using the growth opportunities (GO) variable, defined as the quotient between the intangible assets and company assets.

(6) "Company debt is positively related with the tangibility of the assets" (Myers, 1977, Scott, 1977, Myers and Majluf, 1984, Williamson, 1988, and Harris and Raviv, 1990).

The asset structure (AS), proxy variable introduced to verify this hypothesis, is defined as the quotient between the tangible assets (fixed assets and inventories) and assets.

(7) "The size of the company should be positively related to the level of debt" (Ang, 1992).

The firm size (SIZE) is obtained using the natural logarithm of total assets, with the aim of controlling a possible non-linearity in the data, and the consequent problem of heteroskedasticity.

(8) "There should be a negative relationship between debt ratio and a firm's profitability" (Myers, 1984).

We define the variable profitability (ROA) as the quotient between EBIT and assets.

(9) “A firm's liquidity affects the firm's capital structure” (Ozkan, 2001).

This hypothesis is verified using the liquidity proxy variable (LIQ), defined as the quotient between current assets and current liabilities.

Table A.4 in the annex shows a summary of all the hypotheses defined in this research. Besides, Table A.2 describes in detail all the variables incorporated in the estimated models. 


\section{Pecking order model}

\section{A. Background and theoretical foundation}

The theory emerges as a result of asymmetric information existing in the financial markets, that is, corporate managers often have better information about the health of their companies than outside investors. Apart from the transaction costs of issuing new securities, companies have to accept the information costs arising from asymmetric information. In this way, new securities issued on the financial market could be infra-valued because of informational asymmetries, and this is especially true in the case of new equities. This implies that company managers may decide not to launch potentially profitable projects if they have to be financed by risky financial instruments (Myers and Majluf, 1984). At the same time, the director-owners of SMEs may decide not to seek finance that dilutes their shareholding in the company, and therefore limits their ability to act.

Independently of the above, the theory predicts a hierarchical order in the financing policy of a company. This order begins with those financial sources that are least affected by the costs of information and offer, at the same time, less risk. The preferred source of financing is internally generated funds. This is followed by low risk short-term debt and then higher risk long term debt. The last option is new capital, and this is the financial source with the highest information costs (Donaldson, 1961; Myers, 1984; Myers and Majluf, 1984).

From the perspective of this approach, changes in the level of debt are not motivated by the need to reach a given debt target, but are instead motivated by the need for external financing, once internal resources have been exhausted and assuming that opportunities for profitable investment exist.

One way of testing this theory is by examining financing decisions made after short-term changes in profits and investments, that is, using the theoretical relationship between changes in the level of debt and a firm's need for funds. We propose the following pecking order model - based on Shyam-Sunder and Myers (1999).

$$
\mathrm{D}_{\mathrm{it}}-\mathrm{D}_{\mathrm{it}-1}=\alpha+\beta \cdot \mathrm{FD}_{\mathrm{it}}+\eta_{\mathrm{i}}+\eta_{\mathrm{t}}+\varepsilon_{\mathrm{it}}
$$

$D_{i t}$ being the ratio of total debt, $F D_{i t}$ the financing deficit for period $\mathrm{t}$, given by the difference between investment requirements (variation of fixed assets plus variation 
of working capital) and the cash flow generated by the company (CF). We also include as a component of this deficit, the total of long term debt repayable in period t. This can be estimated from the difference between long-term debt in $\mathrm{t}-1$ and in $\mathrm{t}$. The financing deficit would be approximated as:

$$
\mathrm{FD}=[\Delta \text { Fixed Assets }+\Delta \text { Working Capital }+\Delta \text { Long Term Debt }]-\text { CF }
$$

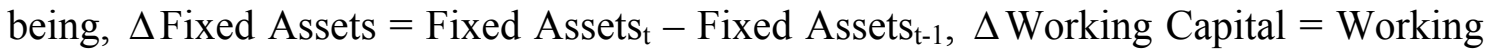

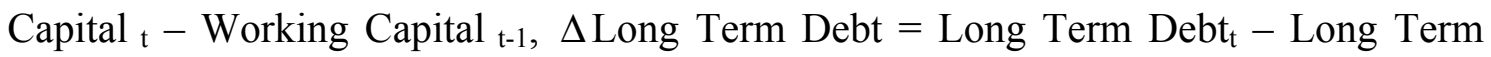
Debt $_{\mathrm{t}-1}, \mathrm{CF}=$ Earnings after taxes + Depreciation.

The pecking order theory establishes that the level of debt should be adjusted to the financing needs of the company, taking as exogenous all the variables that form the earlier financing deficit. In this way, the debt is increased or decreased depending on whether the requirements of the investment exceed or not the available funds, respectively.

Additionally, we will test the pecking order theory with the following regression:

$$
\mathrm{D}_{\mathrm{it}}=\alpha+\beta_{1} \cdot(\mathrm{CF})_{\mathrm{it}}+\beta_{2} \cdot(\text { Age })_{\mathrm{it}}+\beta_{3} \cdot(\mathrm{GO})_{\mathrm{it}}+\eta_{\mathrm{i}}+\eta_{\mathrm{t}}+\varepsilon_{\mathrm{it}}
$$

being, $D$ the total debt ratio, $C F$ the firm's cash flow, Age the natural logarithm of the company age in years, and GO the growth opportunities already defined in the previous section. All of these variables vary over time, and from company to company.

\section{B. Hypotheses and variables}

In equation [4], the hypotheses defined by the pecking order theory are: (i) $\alpha=$ 0 and (ii) $\beta=1$, or approximately equal to 1 , so that the variation in the level of debt coincides with the deficit ( $\triangle \mathrm{D}=\mathrm{FD}$ ); that is, the financing deficit is completely covered by debt. The expression [4] implicitly supposes that companies have not increased their capital during the period under study.

The hypotheses to be tested using the second pecking order model (equation [6]), are the following:

(1) "The level of firm's debt should be negatively related to the volume of cash flow" (Myers, 1984, and Myers and Majluf, 1984). 
(2) "The age of a company should be negatively related to its debt level" (Weston and Brigham, 1981, and Petersen and Rajan, 1994).

(3) "Companies with few investment opportunities and high cash flows should have low debt levels, while companies with strong growth perspectives and reduced cash flows should have high debt ratios" (Myers, 1984).

These hypotheses will be tested using the estimation of parameters corresponding to the implied variables, that is, $\beta_{1}$ for cash flows $(\mathrm{CF}), \beta_{2}$ for Age, and $\beta_{3}$ for growth opportunities (GO).

\section{Data}

\section{A. Sample selection}

The sample of SMEs chosen to make this study has been taken from the SABI (Sistema de Análisis de Balances Ibéricos) database, managed by Grupo Informa, S.A. This database contains economic and financial information on more than 190,000 Spanish companies - from 1992 to the present. The firms in the sample meet the definition established by the European Commission for an SME (Recommendation 96/280/EC, 3 April, 1996) ${ }^{1}$. Firms showing extreme, or inconsistent figures, were excluded from the sample. Finally, the sample contained 6482 SMEs with complete information for the period 1994-1998, resulting in a data panel with 32,410 observations.

These firms are representative of Spanish SMEs because they cover all sectors, except financial and insurance due to their specific financial behaviour and particular nature. The industry classification criteria was adapted from the Spanish Economic Activities National Classification (CNAE-93, Real Decreto 1560/1992), adapted to the statistical notation of economic activities from the European Community (NACE). Table 1 shows this industry classification and the percentage represented by each sector in the whole sample.

\footnotetext{
${ }^{1}$ (1) Less than 250 employees; (2) less than $€ 40$ million invoiced; (3) assets less than $€ 27$ million and (4) independent firm.
} 
Table 1. Sample representation by sector

\begin{tabular}{llcc}
\hline & \multicolumn{1}{c}{ Sectors } & Firms & \% \\
\hline Sector 1 & Agriculture and others & 139 & 2.14 \\
Sector 2 & Manufacturing & 2053 & 31.67 \\
Sector 3 & Electricity, Gas and Water & 21 & 0.32 \\
Sector 4 & Construction & 667 & 10.29 \\
Sector 5 & Commerce, vehicles and others & 2630 & 40.57 \\
Sector 6 & Hotel and catering & 153 & 2.36 \\
Sector 7 & Transport and communications & 237 & 3.66 \\
Sector 8 & Property and rental & 445 & 6.87 \\
Sector 9 & Education, health and others & 137 & 2.11 \\
\hline TOTAL & & 6482 & 100 \\
\hline
\end{tabular}

\section{B. Description of the data}

Firm's capital structure constitutes our dependent variable, and the principal objective of our research. Typically, it is measured using the two following ratios:

- Total debt ratio, $\mathrm{D}_{\mathrm{a}}: \frac{\text { Total debt }}{\text { Total debt }+ \text { Equities }}$, whose possible values range between 0 and 1.

- Total debt ratio, $D_{b}: \frac{\text { Total debt }}{\text { Equities }}$, varying its potential values between 0 and $+\infty$.

Below, we present in Table 2 the main descriptive statistics of these two leverage measures for all the observations. 
Table 2. Descriptive statistics of debt ratio

\begin{tabular}{l|cc}
\hline Statistic & Total debt / $\left(\right.$ Total debt + Equities) $\mathbf{~} \mathbf{~}_{\mathbf{a}} \mathbf{)}$ & Total debt/ Equities $\mathbf{(}_{\mathbf{b}} \mathbf{)}$ \\
\hline Mean & 0.614 & 4.071 \\
Standard deviation & 0.229 & 12.308 \\
Maximum & 0.999 & 851.853 \\
Minimum & 0 & 0 \\
First quartile & 0.457 & 0.859 \\
Second quartile & 0.648 & 1.882 \\
Third quartile & 0.799 & 4.088 \\
Skewness & -0.511 & 36.496 \\
Kurtosis & 2.431 & 2093.429 \\
\hline
\end{tabular}

In Table 2, we can see that the first of the ratios, $D_{a}$, has an asymmetric distribution to the left and is moderately platikurtic; while the second, $\mathrm{D}_{\mathrm{b}}$, is asymmetric to the right and shows a strong leptokurtosis.

The evolution of the mean leverage ratio over the period of analysis, 1994-1998, for the global sample, shows a clear downward tendency, as can be seen in Table 3 . This contrasts with the upward trend of the economy during this period. This phenomenon would appear to agree with the pecking order theory, because during economic booms companies tend to have greater internal resources and so require less external financing.

Table 3. Mean leverage ratio by year

\begin{tabular}{l|cc}
\hline & Total debt / (Total debt + Equities) $\left.\mathbf{( D}_{\mathbf{a}}\right)$ & Total debt / Equities $\left(\mathbf{D}_{\mathbf{b}}\right)$ \\
\hline 1994 & 0.6410 & 5.9251 \\
1995 & 0.6273 & 4.2843 \\
1996 & 0.6104 & 3.7141 \\
1997 & 0.6010 & 3.3694 \\
1998 & 0.5907 & 3.0610 \\
\hline
\end{tabular}

The main statistics of the explanatory variables are shown for the global set of observations in Table 4 below. 
Table 4. Descriptive statistics of the explanatory variables

\begin{tabular}{llllllll}
\hline Variable & Mean & $\begin{array}{l}\text { Standard } \\
\text { deviation }\end{array}$ & Minimum & Maximum & Median & Skewness & Kurtosis \\
\hline ETR & 0.2836 & 0.1165 & 0 & 0.9946 & 0.3196 & -0.6059 & 6.4033 \\
NDTS & 0.0353 & 0.03645 & 0 & 1.2236 & 0.0252 & 4.6027 & 72.4624 \\
DR & 1.0969 & 190.2891 & -12262.33 & 22338.75 & 0.3058 & 89.9581 & 12096.86 \\
GO & 0.0347 & 0.0722 & 0 & 0.9386 & 0.0034 & 3.7089 & 21.3562 \\
AS & 0.4404 & 0.2392 & 0 & 1 & 0.4270 & 0.1975 & 2.2073 \\
Size & 13.8989 & 1.1848 & 8.1682 & 17.1111 & 13.8319 & 0.1376 & 2.7635 \\
ROA & 0.0962 & 0.0884 & -1.0258 & 3.5468 & 0.0792 & 4.8664 & 125.539 \\
CF & 3.0095 & 190.4611 & -330.2389 & 34019 & 0.4958 & 176.5502 & 31519.75 \\
Age & 2.2706 & 0.7488 & 0 & 4.4659 & 2.3026 & -0.4525 & 3.5494 \\
LIQ & 1.9318 & 10.7829 & 0 & 1771.107 & 1.2886 & 139.1836 & 22486.3 \\
\hline
\end{tabular}

ETR: effective tax rate; NDTS: non-debt tax shields; DR: default risk; GO: growth opportunities; AS: asset structure; Size: firm size; ROA: profitability; CF: cash flow; Age: firm age; LIQ: liquidity.

In Table 4 it is worth pointing out that the SMEs in our sample have an average effective tax rate of $28 \%$, which is slightly less than the $30 \%$ tax rate officially established for small companies by Spanish tax legislation (Law 24/2001, 27 December, of Fiscal, Administrative and Social Order Measures). The average age of the SMEs analysed is 10 years - with the youngest company aged 5 and the oldest 87 . The average profitability, in terms of profitability over assets, reached $9.62 \%$ for the period 1994 1998.

Table 5 gives the matrix of correlations among the different variables. It is worth noting that: (i) consistent with the predictions of pecking order theory, the analysis of correlations reveals a negative association between debt and firm profitability and, (ii) the negative correlation between debt and the effective tax rate contradicts the conventional belief that its sign should be positive. 
Table 5. Correlation coefficients of the variables

\begin{tabular}{|c|c|c|c|c|c|c|c|c|c|c|c|c|}
\hline & $\mathbf{D}_{\mathbf{a}}$ & $\mathbf{D}_{\mathbf{b}}$ & $\mathbf{E T R}$ & $\mathbf{N D T S}$ & $\mathbf{D R}$ & $\mathbf{G O}$ & $\mathbf{A S}$ & Size & ROA & CF & Age & LIQ \\
\hline $\mathbf{D}_{\mathbf{a}}$ & 1.0000 & & & & & & & & & & & \\
\hline $\mathbf{D}_{\mathbf{b}}$ & 0.9728 & 1.0000 & & & & & & & & & & \\
\hline ETR & -0.0579 & -0.0610 & 1.0000 & & & & & & & & & \\
\hline NDTS & -0.1174 & -0.1128 & -0.1168 & 1.0000 & & & & & & & & \\
\hline DR & 0.0001 & -0.0015 & 0.0025 & -0.0065 & 1.0000 & & & & & & & \\
\hline GO & 0.0993 & 0.0885 & -0.0308 & 0.2808 & -0.0013 & 1.0000 & & & & & & \\
\hline AS & 0.0474 & 0.0454 & -0.0942 & 0.0975 & -0.0025 & -0.1665 & 1.0000 & & & & & \\
\hline Size & -0.1305 & -0.1261 & 0.0389 & -0.0543 & 0.0045 & -0.0287 & 0.0231 & 1.0000 & & & & \\
\hline ROA & -0.1682 & -0.1667 & 0.0326 & 0.0460 & -0.0045 & 0.0321 & -0.1271 & -0.0402 & 1.0000 & & & \\
\hline CF & 0.0071 & 0.0093 & -0.0025 & -0.0114 & -0.0001 & -0.0063 & -0.0138 & -0.0041 & 0.0074 & 1.0000 & & \\
\hline AGE & -0.3388 & -0.3523 & 0.0433 & 0.0146 & 0.0070 & -0.0498 & 0.0195 & 0.4375 & 0.0705 & -0.0142 & 1.0000 & \\
\hline LIQ & -0.1173 & -0.1305 & -0.0121 & -0.0186 & -0.0000 & -0.0238 & -0.0185 & 0.0143 & 0.0012 & 0.0002 & 0.0284 & 1.0000 \\
\hline
\end{tabular}

\section{Panel data methodology}

The panel character of our data allows us to use panel data methodology for testing our capital structure models discussed in sections 2 and 3, simultaneously combining cross section and time series data. Panel models can be classified into dynamic and static models, depending on whether the lagged dependent variable is included, or not, in these models. Each kind of model needs a different estimation technique in order to achieve efficient and consistent estimators. Let's see in the following subsections what that estimation process is and the main problems that arise from it.

\section{A. Static panel}

In general terms, a static panel data model may be described by the following equation:

$$
y_{i t}=\beta \cdot x_{i t}+\eta_{i}+\eta_{t}+\varepsilon_{i t}^{2}
$$

\footnotetext{
2 This is the typical structure of the two-way error component model. The one-way error component model would not include the temporal specific effect $\eta$, and exclusively consider the firm specific effect.
} 
where the terms incorporated in [7] are the same as those in equation [2], and which have already been explained in section 2 (epigraph A).

In order to estimate the model of equation [7], we have to first identify whether the unobservable individual effects $\left(\eta_{i}\right)$ are random or fixed, that is, if these effects are orthogonal, or not, to the explanatory variables considered in the model. The implications of considering the individual effects as random or fixed are clearly different: in the first case (random effects), it is assumed that every individual effect is an unobservable random variable, independent of the explanatory variables, that belong to a compound random error term. In the second case (fixed effects), these effects are treated as a set of unknown coefficients that can be estimated with the rest of the model parameters. To verify the character of the individual effects in static panel data models, Hausman's specification test is usually employed over the null hypothesis that the individual effects are not correlated with the independent variables $\left[\mathrm{H}_{0}: \mathrm{E}\left(\mathrm{\eta}_{\mathrm{i}} / \mathrm{x}_{\mathrm{it}}\right)=0\right]$. In this sense, if we accept this null hypothesis the individual effects are supposed to be random and, in the opposite case they are supposed to be fixed effects. The random effects model $\left(E\left(\eta_{i} / x_{i t}\right)=0\right)$ needs Generalized Least Squares (GLS) estimation, while the fixed effects model $\left(E\left(\eta_{i} / x_{i t}\right) \neq 0\right)$ can be estimated by Ordinary Least Squares (OLS) over the Within Group transformation ${ }^{3}$.

\section{B. Dynamic panel}

The second kind of panel models, dynamic, could be represented by the following mathematical structure (order 1):

$$
\mathrm{y}_{\mathrm{it}}=\alpha \cdot \mathrm{y}_{\mathrm{it}-1}+\beta \cdot \mathrm{x}_{\mathrm{it}}+\eta_{\mathrm{i}}+\eta_{\mathrm{t}}+\varepsilon_{\mathrm{it}}
$$

The application of static estimations (epigraph A) to dynamic panel regressions, such as equation [8], that include many firms and a limited number of time observations, will result in inconsistent estimators due to correlations that could arise between the unobservable individual effects, the regressors and the error terms, and also due to the existence of regressor endogeneity (Baltagi, 1995). The general estimation approach for these cases, which has been developed in various econometrical literature

\footnotetext{
3 The Within Group regression applies Ordinary Least Squares to the original model [7] transformed or adjusted. The adjustment consists in subtracting the mean of every variable considered: dependent, explanatory and random error.
} 
stances, is based on instrumental variables (IV) estimators (vid. Anderson and Hsiao, 1981, 1982; Arellano and Bond, 1991; Ahn and Schmidt, 1995; Arellano and Bover, 1995), and alternatively, on Generalized Moments Method (GMM) IV estimators (Chamberlain, 1984; Arellano and Bond, 1991; Ahn and Schmidt, 1995; Arellano and Bover, 1995).

Anderson and Hsiao (1982) first suggested a consistent estimation technique for dynamic panel models. Specifically, they suggest $\Delta \mathrm{y}_{\mathrm{it}-2}$ (i.e., $\mathrm{y}_{\mathrm{it}-2}-\mathrm{y}_{\mathrm{it}-3}$ ) assuming we have at least four time observations, or $\mathrm{y}_{\mathrm{it}-2}$ (and also previous lags) as an instrument for the lagged dependent variable in first differences. Both instrument measures are correlated with $\Delta \mathrm{y}_{\mathrm{it}-1}$, but uncorrelated with $\Delta \varepsilon_{\mathrm{it}}$ (depending only on $\varepsilon_{\mathrm{it}}$ and $\varepsilon_{\mathrm{it}-1}$ ), if the level error term $\varepsilon_{i t}$ does not show serial correlation. The estimation is carried out by Two Stage Least Squares (2SLS). This IV technique will provide consistent estimations of model parameters, although not necessarily efficient, because (i) it does not use all the available moment conditions ${ }^{4}$ and (ii) it does not consider the different structure of residual perturbances (Ahn and Schmidt, 1995).

As a solution to the cited problems, Arellano and Bond (1991), using the GMM estimation technique, suggest a dynamic panel data estimator that optimally exploits the linear moment restrictions implicit in these kinds of models ${ }^{5}$. Arellano and Bond (1991) prove that their GMM estimations provide lesser variances than those of the Anderson and Hsiao (1982) IV estimators. We can reason the former assertion by arguing that GMM estimator of Arellano and Bond (1991) enables increasing the instruments used in each period as we move throughout the panel, while the Anderson and Hsiao (1982) estimator employs, for instance, only $\Delta \mathrm{y}_{\mathrm{i}, \mathrm{t}-2}$ to instrument $\Delta \mathrm{y}_{\mathrm{i}, \mathrm{t}-\mathrm{l}}$. The origin of the additional instruments stays on the orthogonality conditions that exist between the lagged values of the dependent variable and the random perturbances. This GMM methodology allows us to control for error correlation throughout the time,

\footnotetext{
4 The moment conditions are conditions over the covariance between the regressors and the error term. The regressors may be orthogonal to the error term, and if this is the case we can use orthogonality conditions, that is, the covariance between the regressors and the error term is zero.

${ }^{5}$ In general terms, a GMM estimator can be obtained for the true parameter, searching the element of the parameter space that enables the construction of a linear combination of the sample crossed parameters, as close to zero as possible (Hansen, 1982).
} 
heteroskedasticity between the different firms, simultaneity, and measurement mistakes due to the use of orthogonality conditions of the variance-covariance matrix.

The GMM estimator validity and consistency depends on the two following assumptions: (i) the lagged value of the dependent variable and other explanatory variables are valid instruments, and (ii) the error terms do not show serial correlation ${ }^{6}$.

The theoretical discussion carried out in this section leads us to formulate the following test for our three firm capital structure models: two of them (the trade-off model described by equation [3] and the pecking order model of equation [6]) will have to be estimated by instrumental variables because of their dynamicity or potential regressor endogeneity. On the contrary, the other pecking order model, formulated in equation [4], will be tested with static panel data methodology, due to its nearness to this kind of functional structure.

\section{Empirical analysis and results}

From panel data of a 6482 non-financial Spanish small and medium enterprises sample, covering the five-year period 1994-1998, we have tested two groups of theoretical capital structure models, trying at the same time to identify the main determinants of SMEs financial policy.

Several regressions were carried out to exploit the panel character of data, trying to control the potential endogeneity problems that could appear while testing the models. Likewise, we tried to control any time effect not contemplated in the models, and also capture the industry effect.

Below we present a revision of the main results obtained in the research for every model, and the different proofs carried out to give robustness to the results.

\footnotetext{
${ }^{6}$ For more details on the GMM estimator validity and consistency tests see Arellano and Bond (1991), and Arellano and Bover (1995).
} 


\section{A. Trade-Off}

In this capital structure model, the estimation techniques employed are (i) Two Stage Least Squares (2SLS) in first differences with Anderson and Hsiao's (1982) estimator, and (ii) GMM with Arellano and Bond's (1991) estimator in first differences. We lose two cross sections in both estimations: one due to the lagged dependent variable $\left(\mathrm{D}_{\mathrm{it}-1}\right)$ and another due to taking first differences to get rid of the firm specific effects $\left(\eta_{\mathrm{i}}\right)$, covering the time period 1996-1998 and ending equation [3] of the model as,

$$
D_{i t}-D_{i t-1}=\alpha \cdot\left(D_{i t-1}-D_{i t-2}\right)+\sum_{k} \beta_{k} \cdot\left(V_{k_{i t}}-V_{k_{i t-1}}\right)+\left(\eta_{t}-\eta_{i t-1}\right)+\left(\varepsilon_{i t}-\varepsilon_{i t-1}\right)
$$

or, also:

$$
\Delta \mathrm{D}_{\mathrm{it}}=\alpha \cdot \Delta \mathrm{D}_{\mathrm{it}-1}+\sum_{\mathrm{k}} \beta_{\mathrm{k}} \cdot \Delta \mathrm{V}_{\mathrm{kit}}+\Delta \eta_{\mathrm{t}}+\Delta \varepsilon_{\mathrm{it}}
$$

where $\Delta$ represents first difference.

IV techniques, such as the ones described above, enable us to control the endogeneity problems shown by certain explanatory variables. Specifically, both EA and ROA could present this kind of endogeneity problem. Consequently, these explanatory variables are not necessarily orthogonal to the error terms, and the OLS regression will result in skewed estimations.

The GMM estimation shows two application levels: (i) Homocedastic one stage estimation and robust one stage estimation, and (ii) Two stage estimation. The latter alternative, which employs the residuals of the one stage estimation to construct an asymptotically weighted optimum matrix, is more efficient than the former if it is supposed that the perturbances show heteroskedasticity for relatively big sample data (Arellano and Bond, 1991; Blundell and Bond, 1998). We will first employ the twostage estimation method and, afterwards, we will apply the one stage robust estimation method, in order to test the consistency of the results.

Below, Table 6 reports the results obtained for the different estimations of our trade-off model [3] with OLS, or in its first differences structure [9], with 2SLS and GMM. Our purpose is to base the analysis on the GMM results, taking the OLS and the 2SLS results as comparative references. All the estimations have been undertaken by the statistical software Stata 7.0 (vid. StataCorp., 2001). 
Table 6. Estimation results of trade-off model [3]

\begin{tabular}{|c|c|c|c|}
\hline Explanatory variable & OLS & $\begin{array}{l}\text { Anderson and Hsiao } \\
\text { (1982), 2SLS }\end{array}$ & $\begin{array}{l}\text { Arellano and Bond } \\
\text { (1991), GMM }\end{array}$ \\
\hline $\mathrm{D}_{\mathrm{it}-1}$ & $\begin{array}{l}0.902 * * \\
(0.002)\end{array}$ & $\begin{array}{c}-0.041^{* *} \\
(0.007)\end{array}$ & $\begin{array}{c}0.138^{* *} \\
(0.024)\end{array}$ \\
\hline ETR & $\begin{array}{l}0.012^{*} \\
(0.005)\end{array}$ & $\begin{array}{l}0.023 * * \\
(0.006)\end{array}$ & $\begin{array}{c}0.054^{* *} \\
(0.012)\end{array}$ \\
\hline NDTS & $\begin{array}{c}-0.284 * * \\
(0.016)\end{array}$ & $\begin{array}{c}-0.099 * * \\
(0.027)\end{array}$ & $\begin{array}{l}-0.421^{*} \\
(0.183)\end{array}$ \\
\hline DR & $\begin{array}{l}-0.000 \\
(0.000)\end{array}$ & $\begin{array}{l}-0.000 \\
(0.000)\end{array}$ & $\begin{array}{l}-0.000 \\
(0.000)\end{array}$ \\
\hline GO & $\begin{array}{c}0.106 * * \\
(0.007)\end{array}$ & $\begin{array}{c}0.105^{* *} \\
(0.013)\end{array}$ & $\begin{array}{l}0.054^{*} \\
(0.028)\end{array}$ \\
\hline AS & $\begin{array}{l}-0.001 \\
(0.002)\end{array}$ & $\begin{array}{c}0.028 * * \\
(0.005)\end{array}$ & $\begin{array}{l}-0.009 \\
(0.013)\end{array}$ \\
\hline Size & $\begin{array}{c}0.000 \\
(0.0004)\end{array}$ & $\begin{array}{l}0.188^{* *} \\
(0.003)\end{array}$ & $\begin{array}{c}0.211^{* *} \\
(0.009)\end{array}$ \\
\hline ROA & $\begin{array}{c}-0.255^{* *} \\
(0.006)\end{array}$ & $\begin{array}{c}-0.215^{* *} \\
(0.009)\end{array}$ & $\begin{array}{c}0.021 \\
(0.028)\end{array}$ \\
\hline LIQ & $\begin{array}{c}-0.0004 * * \\
(0.000)\end{array}$ & $\begin{array}{c}-0.0001 * * \\
(0.000)\end{array}$ & $\begin{array}{l}-0.0002 \\
(0.000)\end{array}$ \\
\hline Number of firms & 6482 & 6479 & 6468 \\
\hline Number of observ. & 25863 & 12910 & 12910 \\
\hline \multicolumn{4}{|c|}{ 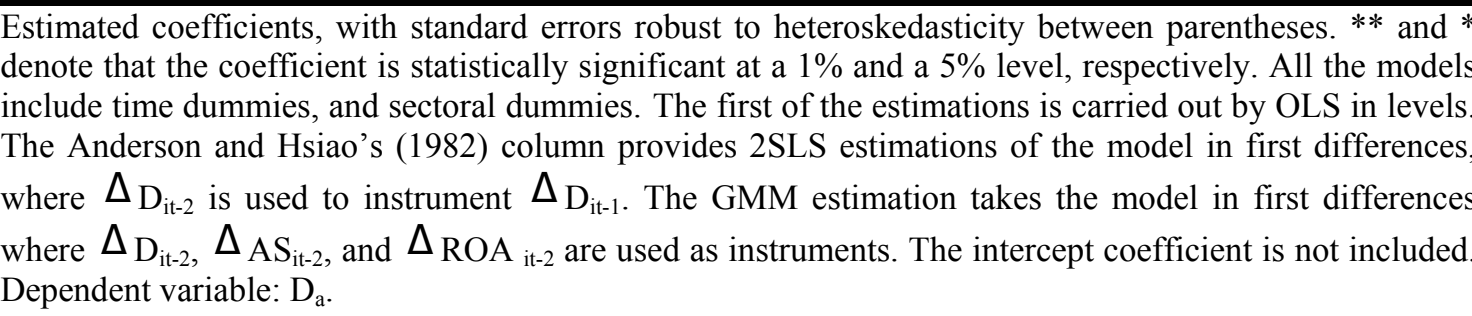 } \\
\hline
\end{tabular}

Considering the results of the most powerful estimation (GMM) as our reference, the acceptance of hypotheses (1), (2), (3) and (7) is verified, while hypotheses (4), (5), (6), (8) and (9) are unconfirmed. These results suggest various reflections.

The empirical evidence obtained indicates that SMEs have a target or optimum leverage ratio, which is explained as a function of some specific characteristics of the firm. Specifically, the estimated value of the parameter associated to the lagged leverage $\left(\alpha=\left(1-\lambda_{\mathrm{it}}\right)\right)$ turned out to be 0.138 , which indicates that the adjustment parameter would be approximately 0.862 . The high value of this adjustment coefficient denotes the high adjustment speed of Spanish SMEs, which is very close to the target leverage. There are also appreciably reduced transaction costs as SMEs probably compare two kinds of costs when adjusting their capital structure: (i) the costs incurred when making the adjustment to the target leverage, and (ii) the costs of staying at an unbalanced position, that is, far from the target. In this manner, the adjustment coefficient will be 
close to one if the costs of being unbalanced are very large compared to the costs of self-adjustment. Alternatively, such a coefficient will be close to zero if the adjustment costs are much higher than the unbalanced costs. Therefore, it can be deducted that Spanish SMEs seem to find the costs of an unbalanced position more burdensome than the costs of the self-adjustment process.

As far as fiscal factors are concerned, the effective tax rate and the non-debt tax shields, we can highlight that both influence SME capital structure. To be precise, the estimated coefficient of the effective tax rate is positive and statistically significant, meaning that the more taxes SMEs have to pay the higher is the use of debt as a way to reduce tax bills. On the other hand, the existence of non-debt tax shields, such as depreciation, reduces the importance of the fiscal advantage of debt.

Contrary to the conventional wisdom, Table 6 shows a positive and statistically significant impact between growth opportunities and firm leverage. However, this positive relationship is consistent with the Michaelas et al. (1999) argument, based on the idea that in SMEs the trade off between independence and financing availability is more pronounced and the major part of debt financing is short term. In this way, the application to the SMEs of Myers' (1977) underinvestment problem, which could be resolved by shortening debt maturity, implies that growth perspectives may be positively related to leverage.

On the other hand, this positive sign could be affected by the proxy used to measure growth opportunities (the proportion represented by intangible assets over total assets), which includes, according to Spanish accounting rules, a large proportion of tangible assets, such as assets financed by leasing, patents, trademarks, etc., and therefore constitutes an imperfect measure of the cited variable. Although it is true that a vast majority of the empirical literature has adopted Tobin's q ratio, or a research and development ratio, as a proxy for investment opportunities, it is practically impossible to get such information for SMEs, especially if the database employed is fed from the mercantile registry and abbreviated financial statements.

As seen in Table 6, firm size and leverage are found to be positively related. This result is the same as that obtained by a considerable number of previous studies (Ocaña et al., 1994; Hutchinson, 1995; Chittenden et al., 1996; Berger and Udell, 1998; Michaelas et al., 1999; Romano et al., 2000). The explanation of this relationship could come from the fact that SMEs have to face higher bankruptcy costs, greater agency costs and bigger costs to resolve the higher informational asymmetries. Even within this 
firm category, SMEs of greater size can access a higher leverage. Consequently, the hypothesis (7) of firm size is confirmed.

Finally, Table 6 shows the non-significance of the variables default risk, asset structure, profitability and liquidity. Default risk has appeared to be not statistically significant under all the estimations techniques, although they all have shown a negative sign (in line with the theory), denoting that the higher a firm's default risk, the lower the debt level. Asset structure, although not significant with GMM, appears with a significant and positive sign under 2SLS estimation, which would demonstrate the necessity of SMEs to provide collateral assets in order to obtain debt financing. As far as profitability and liquidity is concerned, the relationships obtained by OLS and 2SLS are in agreement with hypotheses (8) and (9), although they loose their significance with GMM.

In short, we present in Table 7, both expected and actual relationships between the explanatory variables and the dependent variable of trade-off model according to GMM estimation:

Table 7. Summary of the relations obtained for the trade-off model [3]

\begin{tabular}{l|cc}
\hline \multicolumn{1}{c|}{ Explanatory variable } & Expected relation & Actual relation \\
\hline $\mathrm{D}_{\mathrm{it}-1}$ & + & + \\
$\mathrm{ETR}$ & + & + \\
$\mathrm{NDTS}$ & - & - \\
$\mathrm{DR}$ & - & $\mathrm{n} . \mathrm{s.}$ \\
$\mathrm{GO}$ & - & + \\
$\mathrm{AS}$ & + & $\mathrm{n} . \mathrm{s}$ \\
$\mathrm{Size}$ & + & + \\
$\mathrm{ROA}$ & - & $\mathrm{n} . \mathrm{s}$ \\
LIQ & $+/-$ & $\mathrm{n} . \mathrm{s}$ \\
\hline
\end{tabular}

D: total debt ratio. ETR: effective tax rate. NDTS: non-debt tax shields. DR: default risk. GO: growth opportunities. AS: asset structure. Size: firm size. ROA: profitability. LIQ: liquidity. n.s.: not significant.

\section{B. Pecking order}

According to the theoretical discussion of section 3, we aim to test the pecking order approach with two models. The first is formulated by equation [4], which can be summed up as: 


$$
\Delta \mathrm{D}_{\mathrm{it}}=\alpha+\beta \cdot \mathrm{FD}_{\mathrm{it}}+\eta_{\mathrm{i}}+\eta_{\mathrm{t}}+\varepsilon_{\mathrm{it}}
$$

This expression cannot include increasing capital as a mode of financing because the pecking order theory considers this source as the last option. In order to be sure that firms only choose debt financing once they have completely exhausted their internal resources, and that they will not increase capital beforehand, equation [4] will be estimated over a SMEs subsample within the 6482 SME global sample, which had not increased capital throughout the analysis period (1994-1998). Once applied the previous filter, from the original 6482 SMEs we find 1092 SMEs that increased their capital at some time, so that our definitive subsample mounts up to 5390 SMEs (26950 observations).

Again using the statistical package Stata 7.0 (StataCorp., 2001), the results obtained by the OLS, GLS, and the Within Group estimations are the following:

Table 8. Estimation results of pecking order model [4]

\begin{tabular}{l|ccc}
\hline $\begin{array}{c}\text { Parameter } \\
\alpha\end{array}$ & OLS & $\begin{array}{c}\text { GLS } \\
\text { (Random Effects) }\end{array}$ & $\begin{array}{c}\text { Within Group } \\
\text { (Fixed Effects) }\end{array}$ \\
\hline$\beta$ & $-0.0128^{* *}$ & $-0.0128^{* *}$ & $-0.0130^{* *}$ \\
& $(0.0006)$ & $(0.0006)$ & $0.0006)$ \\
& $0.0000^{* *}$ & $0.0000^{* *}$ & $(0.0000)$ \\
\hline Number of firms & $(0.0000)$ & $(0.0000)$ & 5382 \\
Number of observations & 5390 & 5382 & 21487 \\
\hline \multicolumn{2}{l}{ Estimated coefficients, with standard }
\end{tabular}

Estimated coefficients, with standard errors robust to heteroskedasticity between parentheses. $* *$ and $*$ denote that the coefficient is statistically significant at a $1 \%$ and a $5 \%$ level, respectively. The random effects estimation is carried out by GLS and the fixed effects estimation applies OLS to the Within Group estimator. Dependent variable: $\Delta_{\mathrm{D}_{\mathrm{a}}}$.

As we can see from Table 8, the hypothesis formulated for this first model of pecking order is not completely fulfilled for our sample of SMEs. Despite having carefully selected the SMEs subsample to test the pecking order model [4], it has been difficult to clearly confirm that Spanish SMEs adjust their debt level to their financing requirements. The beta parameter, as shown in Table 8 , although significant by any of the estimation techniques, shows a value close to zero and, therefore, very far from what it should be in theory (i.e., one).

The second of the pecking order models that is also tested is the one represented by equation [6], with the following mathematical expression: 


$$
\mathrm{D}_{\mathrm{it}}=\alpha+\beta_{1} \cdot(\mathrm{CF})_{\mathrm{it}}+\beta_{2} \cdot(\mathrm{Age})_{\mathrm{it}}+\beta_{3} \cdot(\mathrm{GO})_{\mathrm{it}}+\eta_{\mathrm{i}}+\eta_{\mathrm{t}}+\varepsilon_{\mathrm{it}}
$$

The inclusion of variable $C F$ in this model, whose endogeneity has been previously highlighted in the empirical evidence (Hernando and Vallés, 1992), justifies the instrumental variable (IV) estimation. This estimation is undertaken on the original model in first differences and by 2SLS, the method upon which we will base our analysis. Nevertheless, as previously, we will also add OLS estimation as a comparison and to perfect the analysis.

Any dichotomic variable that is constant throughout the time (such as industry dummies), will not be contemplated in the estimation with first differences, as they will be erased when taking time differences for each firm of the panel. Something similar occurs with the variable Age, because it is defined as the number of years of an SME's life and it increases one unit per year, taking a constant value equal to one in a model with first differences. In order to ease this problem, we will use the natural logarithm of Age. Both Age and growth opportunities $(G O)$ are considered exogenous in our analysis, while we assume that $C F$ is endogenous.

Using Stata 7.0 (StataCorp., 2001), the estimation of the pecking order model [6] has provided us the following results:

Table 9. Estimation results of pecking order model [6]

\begin{tabular}{l|cc}
\hline \multicolumn{1}{c|}{ Explanatory variable } & OLS & 2SLS \\
\hline CF & 0.0000 & $-0.0002^{* *}$ \\
& $(0.000)$ & $(0.000)$ \\
Age & $-0.101^{* *}$ & $-0.033^{* *}$ \\
& $(0.002)$ & $(0.010)$ \\
GO & $0.262^{* *}$ & $0.146^{* *}$ \\
& $(0.017)$ & $(0.016)$ \\
\hline Number of firms & 6482 & 6450 \\
Number of observations & 32050 & 12857 \\
\hline Esti
\end{tabular}

Estimated coefficients, with standard errors robust to heteroskedasticity between parentheses. ** and * denote that the coefficient is statistically significant at a $1 \%$ and a $5 \%$ level, respectively. The first of the estimations corresponds to OLS in levels, while the second provides 2SLS estimations, with Anderson and Hsiao's (1982) estimator, of the model in first differences. In this latter estimation, $\Delta_{\mathrm{CF}_{\mathrm{it}-2}}$ is used to instrument $\Delta_{\mathrm{CF}_{\mathrm{it}}}$. The intercept coefficient is not included. Dependent variable: $\mathrm{D}_{\mathrm{a}}$.

Given the 2SLS results from Table 9, we find that all the formulated hypotheses for this pecking order model (1), (2) and (3) are verified. 
Cash flow is negatively related to firm leverage, so that those SMEs that generate most internal resources are the ones with a lower leverage. This result is consistent with pecking order theory predictions, which point to firms' preferences for financing their investments using internal resources instead of external resources.

The results presented in Table 9 show a negative and statistically significant impact of age upon SMEs financing. The older SMEs may have generated sufficient internal resources to not depend as much on debt as the younger SMEs, whose dependence on external resources will be greater.

Finally, the hypothesis referred to growth opportunities in the scope of pecking order theory is fulfilled, obtaining a positive and significant relation between this variable and firm leverage. The previous relationship was already found in the trade-off model. In short, those SMEs that have more investment opportunities will need more financing resources, forcing them to resort to debt financing.

The empirical testing of both pecking order models proposed in our study, have provided the following results:

Table 10. Summary of the relations obtained for the pecking order models [4] and [6]

\begin{tabular}{l|cc}
\hline \multicolumn{1}{c|}{ Explanatory variable } & Expected relation & Actual relation \\
\hline FD & $+(\simeq 1)$ & $+(\simeq 0)$ \\
CF & - & - \\
Age & - & - \\
GO & + & + \\
\hline
\end{tabular}

FD: financing deficit. CF: cash flow. Age: firm age. GO: growth opportunities. n.s.: not significant.

The apparent disparity of the results of both pecking order models, as shown in Table 10, could be due to the small length of the data and also to the difficulties to measure the Financing Deficit $(F D)$ variable.

\section{Robustness of the results}

A set of tests was undertaken on our models to verify the degree of consistency and robustness of the results obtained. 
In the GMM estimation (trade-off model), Sargan's test of overidentifying restrictions was carried out, whose associated statistic is asymptotically distributed as chi-square under the null hypothesis of instrument validity. This test is important because the GMM estimator provides consistent estimations only if a valid set of instruments is employed. Its value, given in Table 11, denotes that we can accept the null hypothesis on the suitability of instruments for a $15.56 \%$ significance level.

Likewise we have carried out the tests of absence of both first and second order autocorrelation of residuals. Again, the consistency of the GMM estimators relies on the absence of the cited correlations, though it is true that the key serial correlation of the residuals is the second order correlation, enabling the first order correlation to adopt a value different from zero (Arellano and Bond, 1991). The values of these tests, which are also presented in Table 11, confirm the absence of second order autocorrelation.

Table 11. Statistics tests for the trade-off model [3]

\begin{tabular}{l|ccc}
\hline & OLS & $\begin{array}{c}\text { Anderson and Hsiao } \\
(\mathbf{1 9 8 2}), \mathbf{M C 2 E}\end{array}$ & $\begin{array}{c}\text { Arellano and Bond } \\
\mathbf{( 1 9 9 1 )}, \mathbf{M G M}\end{array}$ \\
\hline $1^{\text {st }}$ order autocorrelation & --- & --- & -8.32 \\
$2^{\text {nd }}$ order autocorrelation & --- & --- & 0.0000 \\
Wald test 1 (d.f.) & $8839.12(20)$ & $697.16(10)$ & 0 \\
$\mathrm{P}-$ value (F) & 0.0000 & 0.0000 & $68.90(15)$ \\
Wald test 2 (d.f.) & $6.77(3)$ & --- & 0.0000 \\
$\mathrm{P}-$ value (F) & 0.0001 & --- & \\
Wald test 3 (d.f.) & $6.93(8)$ & --- & - \\
$\mathrm{P}-$ value (F) & 0.0000 & --- & $5.23(3)$ \\
Sargan test (d.f.) & & & 0.1556 \\
$\mathrm{P}-$ value $\left(\chi^{2}\right)$ & --- & & - \\
\hline
\end{tabular}

d.f.: degrees of freedom. The first two tests indicate the existence, or not, of first and second order autocorrelation, respectively, in the residuals. Wald test 1 is a test of joint significance of the estimated coefficients. Wald test 2 is a test of joint significance of the time dummies. Wald test 3 is a test of joint significance of the industry dummies. The Sargan test enables us to verify the suitability of the instruments; the degrees of freedom are calculated, in this case, as the difference between the number of instruments and regressors.

To test the degree of joint significance of the regressors, Wald's test (FisherSnedecor F statistic) was undertaken in three ways: (i) on the estimated coefficients, which is asymptotically distributed as chi-square under the null hypothesis of no 
relationship, (ii) on the time dummies and (iii) on the industry dummies. Its values are included in Tables 11 and 12, and according to those results we reject the null hypothesis of relationship absence and, therefore, the joint significance of all the variables is confirmed.

We sum up the information of the previous tests for every estimated model in Tables 11 and 12 .

Table 12. Statistics tests for the pecking order models [4] and [6]

\begin{tabular}{l|ccccc}
\hline & OLS & Random Effects & Fixed Effects & OLS & 2SLS \\
& {$[4]$} & {$[4]$} & {$[4]$} & {$[6]$} & {$[6]$} \\
\hline Wald test (d.f.) & $157.85(1)$ & --- & 0.0000 & 0.0000 & 0.0000 \\
P - value (F) & 0.0000 & & & & \\
Wald test (d.f.) & & $157.85(1)$ & --- & \\
$\mathrm{P}$ - value $\left(\chi^{2}\right)$ & --- & 0.0000 & & \\
\hline
\end{tabular}

d.f.: degrees of freedom. Test of joint signification of the estimated coefficients.

We have meticulously examined to see if the variables employed in the study are predetermined or, in contrast, they are strictly exogenous regarding the error term. The validity of the instruments depends on the relation between the regressors and the random error. In order to test if $\mathrm{x}_{\mathrm{it}}$ is predetermined or not with respect to $\varepsilon_{\text {it }}$, we start using instruments with 2 lags for every variable included in the set of instruments. We next add $x_{i, t-1}$ to the existing instruments to analyse the potential bias that could appear from the correlation between $\mathrm{x}_{\mathrm{i}, \mathrm{t}-\mathrm{l}}$ and the error term with first differences $\Delta \varepsilon_{\mathrm{it}}$. If there really is a measurement error, then the estimated coefficients of the explanatory variables should be reduced, which would suggest a downward bias due to the joint determination of $\mathrm{x}_{\mathrm{i}, \mathrm{t}-1}$ and $\varepsilon_{\mathrm{it}-1}$. Repeating the previous procedure for every variable, we can see if there is, or not, some predetermined variable with respect to $\varepsilon_{\text {it }}$. We also checked the possibility of strict endogeneity of the variables with respect to $\varepsilon_{\text {it }}$ including current values. If the estimations of the coefficients are reduced, then we can conclude that none of the variables is strictly exogenous with respect to $\varepsilon_{\text {it }}$.

Furthermore, we carried out the estimation analysis with alternative measurements of the dependent variable and some other firm specific characteristics 
(effective tax rate, size, age), without obtaining significant differences from the original estimations ${ }^{7}$.

Lastly, we have estimated the capital structure trade-off model [3], by the one stage robust GMM version, without substantially differing from the results of the twostage version. The results are given in Table 13.

Table 13. Estimation by GMM, robust version of Arellano and Bond (1991)

\begin{tabular}{l|c}
\hline $\mathbf{D}_{\text {it-1 }}$ & $0.139^{* *}$ \\
& $(0.024)$ \\
ETR & $0.049^{* *}$ \\
& $(0.012)$ \\
NDTS & $-0.420^{*}$ \\
& $(0.183)$ \\
DR & -0.000 \\
GO & $(0.000)$ \\
& $0.058^{*}$ \\
AS & $(0.028)$ \\
Size & -0.009 \\
& $(0.013)$ \\
ROA & $0.211^{* *}$ \\
LIQ & $(0.009)$ \\
& 0.014 \\
Number of firms & $(0.028)$ \\
Number of observations & -0.0002 \\
& $(0.0002)$ \\
\hline
\end{tabular}

Estimated coefficients, with standard errors robust to heteroskedasticity between parentheses. $* *$ and $*$ denote that the coefficient is significant at a $1 \%$ and a $5 \%$ level, respectively. Dependent variable: total debt ratio $\left(\mathrm{D}_{\mathrm{a}}\right)$.

${ }^{7}$ If requested, further information is available from the authors. 


\section{Conclusions}

This paper shows empirical evidence related to the capital structure of small and medium sized Spanish companies as taken from a large data panel covering the period 1994-1998. The hypotheses tested were derived from pecking order and trade-off models. In general, both theoretical approaches appear to help explain the financial behaviour of these companies and the results obtained can be considered robust.

Regarding trade-off theory, the results clearly indicate the existence of an optimal or target debt level where firms partially converge - the transaction costs not being excessively high. The evidence seems to confirm that Spanish SMEs adjust their target ratio very quickly - faster than publicly listed companies. Our parameter for adjustment speed, $\alpha$, was 0.86 compared to the estimate of 0.79 produced by Miguel and Pindado (2001) for Spanish listed companies. In addition, the adjustment coefficient obtained is clearly higher than that found at the United States of America by ShyamSunder and Myers (1999) - 0.41 - and Fama and French (2002) - 0.07-0.1 for dividend firm payers and 0.15-0.18 for non-payers. Small Spanish firms seem to find the costs of an unbalanced position higher than the costs of the process of adjustment. As a result, it is confirmed that bank financing, typical in these companies, offers more advantages than obtaining funds from the capital markets.

With respect to pecking order theory, the reduced value parameter $\beta$ (equation [4]) seems to indicate that small Spanish firms do not adjust their level of debt to their financial needs. It is possible that this relation would improve with a larger data panel, as the econometric techniques used have limited our analysis period. Nevertheless, the hypotheses put forward regarding cash flows, firm age, and growth opportunities have been clearly confirmed. 


\section{APPENDIX}

Table A.1. Dependent variables description

\begin{tabular}{l|c}
\hline Total Debt Ratio $\mathrm{D}_{\mathrm{a}}$ & $\frac{\text { Total debt }}{\text { Total debt }+ \text { Equities }}$ \\
\hline Total Debt Ratio $\mathrm{D}_{\mathrm{b}}$ & $\frac{\text { Total Debt }}{\text { Equities }}$ \\
\hline
\end{tabular}

Table A.2. Explanatory variables description

\begin{tabular}{l|c}
\hline Effective Tax Rate (ETR) & $\begin{array}{c}\frac{\text { Taxes }}{\text { EAIBT }} \text { where EAIBT denotes } \\
\text { Earnings after Interest and before } \\
\text { Tax. }\end{array}$ \\
\hline Non-Debt Tax Shields (NDTS) & $\begin{array}{c}\text { Depreciation }, \text { where Depreciation is } \\
\text { Total assets } \\
\text { taken as a flow variable. }\end{array}$ \\
\hline Default Risk (DR) & $\begin{array}{c}\frac{\text { Interests expenses }}{\text { EBIT }} \text {, where EBIT } \\
\text { denotes Earnings before Interest and } \\
\text { Tax. }\end{array}$ \\
\hline Growth Opportunities (GO) & $\frac{\text { Intangible assets }}{\text { Total assets }}$ \\
\hline Asset Structure (AS) & $\frac{\text { Tangible assets+Inventories }}{\text { Total assets }}$ \\
\hline Size & Natural logarithm of total assets \\
\hline Profitability (ROA) & $\frac{\text { EBIT }}{\text { Total assets }}$ \\
\hline Cash Flow (CF) & $\frac{\text { EBIT+Depreciation }}{\text { Fixed asset }}$ \\
\hline Age & $\begin{array}{c}\text { Natural logarithm of number of years } \\
\text { of firm's life }\end{array}$ \\
\hline Liquidity (LIQ) & $\frac{\text { Current assets }}{\text { Current liabilities }}$ \\
\hline
\end{tabular}


Table A.3. Capital structure models

\begin{tabular}{c|c}
\hline TRADE-OFF [3] & $\mathrm{D}_{\mathrm{it}}=\delta+\alpha \cdot \mathrm{D}_{\mathrm{it}-1}+\sum_{\mathrm{k}} \beta_{\mathrm{k}} \cdot \mathrm{V}_{\mathrm{kit}}+\eta_{\mathrm{i}}+\eta_{\mathrm{t}}+\varepsilon_{\mathrm{it}}$ \\
PECKING ORDER [4] & $\mathrm{D}_{\mathrm{it}}-\mathrm{D}_{\mathrm{it}-1}=\alpha+\beta \cdot \mathrm{FD}_{\mathrm{it}}+\eta_{\mathrm{i}}+\eta_{\mathrm{t}}+\varepsilon_{\mathrm{it}}$ \\
PECKING ORDER [6] & $\mathrm{D}_{\mathrm{it}}=\alpha+\beta_{1} \cdot \mathrm{CF}_{\mathrm{it}}+\beta_{2} \cdot \mathrm{Age}_{\mathrm{it}}+\beta_{3} \cdot \mathrm{GO}_{\mathrm{it}}+\eta_{\mathrm{i}}+\eta_{\mathrm{t}}+\varepsilon_{\mathrm{it}}$ \\
\hline
\end{tabular}

Table A.4. Empirical hypotheses

\section{TESTED HYPOTHESES}

MODEL

(1) "Firms follow a process of capital structure adjustment that leads to an optimal leverage level over the long-term"

(2) "The effective tax rate should be positively related to the debt level"

(3) "Non-debt tax shields ought be negatively related to firm debt"

(4) "Default risk should be negatively related to the firm's debt ratio"

(5) "Companies with greater growth opportunities will have a smaller debt ratio"

TRADE - OFF [3]

(6) "Firm debt is positively related with assets tangibility"

(7) "The size of the company should be positively related to the level of debt"

(8) "There should be a negative relationship between debt ratio and firm's profitability"

(9) "A firm's liquidity affects the firm's capital structure"

(1) "The financing deficit of Spanish SMEs is covered by debt"

PECKING ORDER

[4]

(1) "Firm debt level should be negatively related to the volume of firm cash flows"

(2) "The age of a company should be negatively related to its debt level"

(3) "Firms with few investment opportunities and high cash flows should

PECKING ORDER

[6] have low debt levels, while firms with strong growth perspectives and reduced cash flows should have high debt ratios" 


\section{References}

Ahn, S. C. and Schmidt, P., 1995, "Efficient estimation of models for dynamic panel data", Journal of Econometrics, 68, 5-27.

Allen, D. E. and Clissold, M. R., 1998, "A direct test of the pecking order hypothesis in an Australian context", in Bos, T. and Featherston, T. (eds.), Advances in Pacific Basin Financial Markets, IV, JAI Press Inc., Greenwood, Connecticut, 335-357.

Anderson, T. W. and Hsiao, C., 1981, "Estimation of dynamic models with error components", Journal of the American Statistical Association, 76, 598-606.

Anderson, T. W. and Hsiao, C., 1982, "Formulation and estimation of dynamic models using panel data", Journal of Econometrics, 18, 47-82.

Ang, J. S., 1976, "The intertemporal behaviour of corporate debt policy", Journal of Financial and Quantitative Analysis, 11, November, 555-566.

Ang, J. S., 1992, "On the theory of finance for privately held firms", The Journal of Small Business Finance, 1 (3), 185-203.

Antoniou, A.; Guney, Y. and Paudyal, K., 2002, "Determinants of corporate capital structure: evidence from European countries", Mimeo, Social Science Research Network (SSRN).

Arellano, M. and Bond, S., 1991, "Some tests of specification for panel data: Monte Carlo evidence and an application to employment equations", The Review of Economic Studies, 58, 277-297.

Arellano, M. and Bover, O., 1995, "Another look at the instrumental - variable estimation of error - components models", Journal of Econometrics, 68, 29-52.

Auberbach, A. J., 1985, "Real determinants of corporate leverage", in B. M. Friedman (ed.), Corporate capital structures in the United States, University of Chicago Press, Chicago, 301-322.

Baltagi, B. H., 1995, “Econometric analysis of panel data”, John Wiley \& Sons, New York.

Banerjee S.; Heshmati, A. and Wihlborg, C., 2000, "The dynamics of capital structure", SSE/EFI Working Paper Series in Economics and Finance, 333, Stockholm School of Economics.

Berger, A. N. and Udell, G. F., 1998, "The economics of small business finance: the roles of private equity and debt markets in the financial growth cycle", Journal of Banking and Finance, 22, 613-673.

Blundell, R. and Bond, S., 1998, "Initial conditions and moment restrictions in dynamic panel data models", Journal of Econometrics, 87, 115-143. 
Bradley, M.; Jarrell, G. A. and Kim, E. H., 1984, "On the existence of an optimal capital structure: theory and evidence", The Journal of Finance, 39 (3), July, 857-878.

Chamberlain, G., 1984, "Panel data", in Griliches, Z. and Intriligator, M.D. (eds.), Handbook of Econometrics, II, Chapter 22, Elsevier Science Publishers BV, 1248-1318.

Chirinko, R. S. and Singha, A. R., 2000, “Testing static tradeoff against pecking order models of capital structure: a critical comment”, Journal of Financial Economics, 58, 417-425.

Chittenden, F.; Hall, G. and Hutchinson, P., 1996, "Small firm growth, access to capital markets and financial structure: review of issues and an empirical investigation", Small Business Economics, 8, 59-67.

DeAngelo, H. and Masulis, R. W., 1980, "Optimal capital structure under corporate and personal taxation", Journal of Financial Economics, 8, 3-29.

Donaldson, G., 1961, "Corporate debt capacity: a study of corporate debt policy and the determination of corporate debt capacity", Graduate School of Business, Harvard University Press, Boston, Mass.

Fama, E. F. and French, K. R., 2002, "Testing trade - off and pecking order predictions about dividends and debt", The Review of Financial Studies, 15 (1), March, 1-33.

Graham, J. R., 1996, "Debt and the marginal tax rate", Journal of Financial Economics, 41, May, 41-73.

Hansen, L. P., 1982, "Large sample properties of Generalized Method of Moments estimators", Econometrica, 50 (4), 1029-1054.

Harris, M. and Raviv, A., 1990, "Capital structure and the informational role of debt", The Journal of Finance, 45 (2), June, 321-349.

Haugen, R. A. and Senbet, L. W., 1986, "Corporate finance and taxes: a review", Financial Management, 15 (3), Autumn, 5-21.

Hernando, I. and Vallés, J., 1992, "Inversión y restricciones financieras: evidencia en las empresas manufactureras españolas", Moneda y Crédito, 195, 185-222.

Hovakimian, A.; Opler, T. and Titman, S., 2001, "The debt - equity choice", Journal of Financial and Quantitative Analysis, 36 (1), March, 1-24.

Hutchinson, P., 1995, "The capital structure and investment decision of small owner - managed firm: some exploratory issues", Small Business Economics, 7, 231-239.

Jalilvand, A. and Harris, R. S., 1984, "Corporate behavior in adjusting to capital structure and dividend targets: an econometric study", The Journal of Finance, 39 (1), March, 127145 . 
Jensen, M. C., 1986, “Agency costs of free cash flow, corporate finance, and takeovers", The American Economic Review, 76 (2), May, 323-329.

Jensen, M. C. and Meckling, W. H., 1976, "Theory of the firm: managerial behavior, agency costs and ownership structure", Journal of Financial Economics, 3, 305-360.

Kim, E. H., 1978, "A mean-variance theory of optimal capital structure and corporate debt capacity", The Journal of Finance, 33 (1), March, 45-63.

Kraus, A. and Litzenberger, R. H., 1973, "A state-preference model of optimal financial leverage", The Journal of Finance, 28 (4), September, 911-922.

Lev, B. and Pekelman, D., 1975, "A multiperiod adjustment model for the firm's capital structure", The Journal of Finance, 30 (1), March, 75-92.

Mackie - Mason, Jeffrey K., 1990, "Do taxes affect corporate financing decisions?", The Journal of Finance, 45 (5), December, 1471-1493.

Marsh, P., 1982, "The choice between equity and debt: an empirical study", The Journal of Finance, 37 (1), March, 121-144.

Michaelas, N.; Chittenden, F. and Poutziouris, P., 1999, "Financial policy and capital structure choice in UK SMEs: empirical evidence from company panel data", Small Business Economics, 12, 113-130.

Miguel, A. de and Pindado, J., 2001, "Determinants of capital structure: new evidence from Spanish panel data", Journal of Corporate Finance, 7, 77-99.

Modigliani, F. and Miller, M. H., 1963, "Corporate income taxes and the cost of capital: a correction”, The American Economic Review, 53 (2), June, 433-443.

Myers, S. C., 1977, "Determinants of corporate borrowing”, Journal of Financial Economics, 5, 147-175.

Myers, S. C., 1984, "The capital structure puzzle", The Journal of Finance, 39 (3), July, 575592.

Myers, S. C. and Majluf, N. S., 1984, "Corporate financing and investment decisions when firms have information that investors do not have", Journal of Financial Economics, 13, 187-221.

Nuri, J. and Archer, S., 2001, "Target adjustment model against pecking order model of capital structure", European Financial Association Annual Meeting, June, Lugano, Switzerland.

Ocaña, C.; Salas, V. and Vallés, J., 1994, "Un análisis empírico de la financiación de la pequeña y mediana empresa manufacturera española: 1983-1989”, Moneda y Crédito, 199, 5796. 
Omet, G., 2001, "Dynamic capital structure: evidence from Jordanian company panel data", Paper presented at the $8^{\text {th }}$ Annual Conference of the Multinational Finance Society, June 23 - 27, Lake Garda, Italy.

Opler, T. and Titman, S., 1993, "The determinants of leveraged buyout activity: free cash flows vs. financial distress costs", The Journal of Finance, 48, 1985-1999.

Ozkan, A., 2000, "An empirical analysis of corporate debt maturity structure", European Financial Management, 6 (2), 197-212.

Ozkan, A., 2001, "Determinants of capital structure and adjustment to long run target: evidence from UK company panel data", Journal of Business Finance \& Accounting, 28 (1) \& (2), January/March, 175-198.

Petersen, M. A. and Rajan, R. G., 1994, "The benefits of lending relationships: evidence from small business data", The Journal of Finance, 49 (1), March, 3-37.

Rajan, R. G. and Zingales, L., 1995, "What do we know about capital structure? Some evidence from international data", The Journal of Finance, 50 (5), December, 1421-1460.

Romano, C. A.; Tanewski, G. A. and Smyrnios, K. X., 2000, "Capital structure decision making: a model for family business", Journal of Business Venturing, 16 (3), 285-310.

Sargan, J. D., 1958, “The estimation of economic relationships using instrumental variables", Econometrica, 26, 393-415.

Scott, J. H. Jr., 1976, "A theory of optimal capital structure", The Bell Journal of Economics, 34, Spring, 33-54.

Scott, J. H. Jr., 1977, "Bankruptcy, secured debt, and optimal capital structure", The Journal of Finance, 32, March, 1-19.

Shyam-Sunder, L. and Myers, S. C., 1999, "Testing static tradeoff against pecking order models of capital structure", Journal of Financial Economics, 51, 219-244.

StataCorp., 2001, "Stata Statistical Software: Release 7.0", College Station, TX: Stata Corporation.

Stulz, R. M., 1990, "Managerial discretion and optimal financing policies", Journal of Financial Economics, 26, 3-27.

Taggart, R. A. Jr., 1977, “A model of corporate financing decisions", The Journal of Finance, 32 (5), December, 1467-1484.

Titman, S. and Wessels, R., 1988, "The determinants of capital structure choice", The Journal of Finance, 43 (1), March, 1-19.

Weston, J.F. and Brigham, E. F., 1981, "Managerial Finance" $7^{\text {th }}$ edition, The Dryden Press. 
Williamson, O., 1988, "Corporate finance and corporate governance", The Journal of Finance, 43 (3), July, 567-591.

Zingales, L., 2000, "In search of new foundations", The Journal of Finance, 55 (4), August, 1623-1653. 